Rajesh, A, Sathasivampillai, SV, Rajamanoharan, PRS. International Journal of Science Letters (IJSL). 2021. 3(1): 65-72.

\title{
Medicinal values of a horticultural plant - Coleus hadiensis (Forssk.) A. J.
} Paton

\author{
Authinarayanan $\operatorname{Rajesh}^{1}{ }^{\mathrm{D}}$, Saravanan Vivekanandarajah Sathasivampillai ${ }^{2,3^{*} \mathrm{D}}$, \\ Pholtan Rajeev Sebastian Rajamanoharan ${ }^{4,5}$
}

\author{
${ }^{1}$ Department of Medicinal Botany, The Tamil Nadu Dr. M.G.R. Medical University, \\ Chennai/India \\ ${ }^{2}$ KnowledgeLink Group, Inc., Waltham, MA 02451, USA \\ ${ }^{3}$ Boigai Institute, Batticaloa/Sri Lanka \\ ${ }^{4}$ Eastern Provincial Herbal Garden Management Center, Trincomalee/Sri Lanka \\ ${ }^{5}$ Department of Siddha Toxicology, The Tamil Nadu Dr. M.G.R. Medical University, \\ Chennai/India
}

\begin{abstract}
Coleus hadiensis (Forssk.) A.J.Paton is a horticultural herb that goes to the Lamiaceae family. This plant species has been using to treat diarrhea, skin and digestive disorders, diabetes, and carcinoma in ethnomedicines. This minireview work purposes to analyze, summarize, and document the reported bioactivities of $C$. hadiensis. Suitable published works were obtained employing the Web of Science, Scopus, PubMed, Semantic Scholar, and ScienceDirect databases from 1900 to December 2020. Hitherto, in vitro level of scientific evidence is the highest level of scientific evidence available for the bioactivities of this plant species. Various parts of $C$. hadiensis exhibited antioxidant, antibacterial, anti-inflammatory, anticancer, and antimalarial activities in a range of assays. To date, eight bioactive (antimalarial and antioxidant) compounds have been isolated from $C$. hadiensis. This minireview analyzed, summarized, and documented the reported bioactivities of $C$. hadiensis. In addition, this minireview provides a basis for further bioactivities researches using $C$. hadiensis in future.
\end{abstract}

Article History

Received 11.11.2020 Accepted 10.01.2021

\section{Introduction}

Coleus hadiensis (Forssk.) A.J.Paton [synonyms: Plectranthus hadiensis (Forssk.) Schweinf. ex Sprenger; Plectranthus zatarhendivar. tomentosus (Benth.) Codd] is a horticultural herb that goes to the Lamiaceae family (Figure 1). This plant species grows up to

\footnotetext{
${ }^{2,3}$ Correspondence: vivekanandarajahs@yahoo.co.uk
} 
$1.5 \mathrm{~m}$ high and $1 \mathrm{~m}$ broad. Its stems are semi-succulent and red at the lowest part. Leaves are alternately organized and they are oval to round shape, from 35 to $100 \mathrm{~mm}$ broad, soft, gentle, furry, occasionally multicolored. The blossoming is $50 \mathrm{~cm}$ lengthy and contains lateral divisions. The flowers are white or violet and exist 1 to $3 \mathrm{~cm}$ at a distance. The conservation status of $C$. hadiensis is Least Concern and it is usually grown in forest, and grassland. The grow soil is well drained rich soil (Kew Science, 2020). It is native to Asia (Sri Lanka, Maldives, and Yemen) and Africa (Angola, Mozambique, Malawi, South Africa, Ethiopia, Eritrea, Kenya, Chad, Egypt, Djibouti, Swaziland, Rwanda, Zimbabwe, Somalia, Zaïre, Tanzania, and Uganda) (Kew Science, 2020). C. hadiensis has the name Iruveli in Tamil. This plant species has been using to treat diarrhea, skin and digestive disorders, inflammations, coughs, diabetes, and carcinoma in ethnomedicines (Lukhoba et al., 2006; Van Zyl et al., 2008; Rice et al., 2011; Menon et al., 2013; Sathasivampillai et al., 2015; 2017; 2018; Sripathi et al., 2018). Phytochemicals including rosmarinic acid, chrysosplenol D, desacetyl plectranthone, quercetin, casticin, ayanin, (+)-plectranthone, piperitone oxide, L-fenchone, $\beta$ farnesene, copaene, 2,3-dimethyl hydroquinone, $\alpha$-caryophyllene, 1,8-naphthalenedione, limonene, copaene, 8,11,15-eicosatrienoic acid, $\beta$-cubebene, $\beta$-farnesene, $\alpha$-caryophyllene, 2 isopropenyl-5-methylhex-4-enal, germacrene $\mathrm{D}$, piperitone oxide, $\delta$-cadinene, disophenol, $\mathrm{p}$ cymen-8-ol, isolongifolan-8-ol, $\delta$-cadinol, $\alpha$-hydroxymyristic acid, p-cymen-3-ol, octern-3-ol, linalool, nerol, z-citral, geraniol, neryl acetate, $\alpha$-copaene, geranyl acetate, $\alpha$-cadinene, $\alpha$ cadinol, $\beta$-cubebene, and valencene have been discovered in this plant species (Menon and Gopalakrishnan, 2015a; Sripathi and Ravi, 2017; Sripathi et al., 2018; Ji et al., 2019).

As there is no systematic review regarding the bioactivities of $C$. hadiensis, this minireview work purposes to analyze, summarize, and document the reported bioactivities of C. hadiensis. This minireview will be an advantageous for future bioactivities and phytochemistry related researches of $C$. hadiensis.

Suitable published works were obtained employing the Web of Science, Scopus, PubMed, Semantic Scholar, and ScienceDirect databases from 1900 to December 2020. "Coleus hadiensis", "Plectranthus hadiensis", and "Plectranthus zatarhendi var. tomentosus" were used as search terms and the subjects were narrowed down to Biology, Chemistry, Medicine, Agriculture, Pharmacology, Pharmaceutics, Toxicology, Biochemistry, Genetics, Molecular Biology, and Multidisciplinary. 


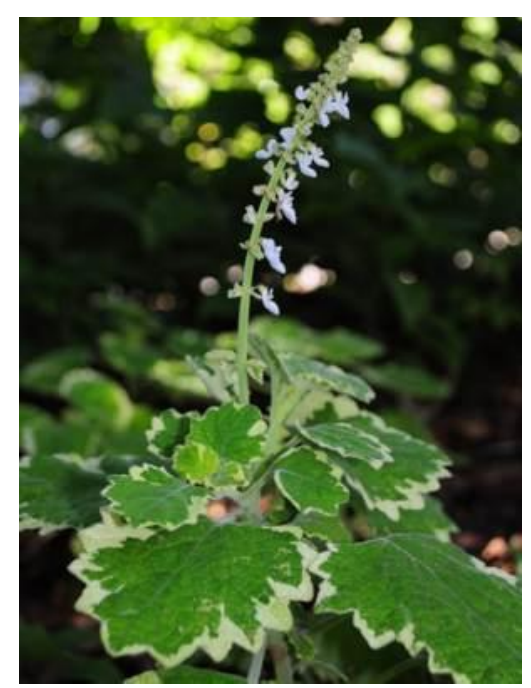

Figure 1. Coleus hadiensis (Forssk.) A. J. Paton (http://pza.sanbi.org/coleus-hadiensis)

\section{Reported Bioactivities of C. hadiensis}

Reported bioactivities of $C$. hadiensis have been listed on Table 1. Hitherto, in vitro level of scientific evidence is the highest level of scientific evidence available for the bioactivities of this plant species. Various parts of $C$. hadiensis exhibited antioxidant, antibacterial, antiinflammatory, anticancer, and antimalarial activities in a range of assays (Van Zyl et al., 2008; Mothana et al., 2010; Menon et al., 2010; 2011; 2012; 2014; Menon and Gopalakrishnan, 2015; Sripathi and Ravi, 2017; Rijo et al., 2018; Sripathi et al., 2018; Ji et al., 2019). A larger number of studies reported the antioxidant activities of this plant species and the aerial part and ethanol extracts were used in the majority of the investigations. To date, eight bioactive compounds (ayanin, casticin, chrysosplenol D, luteolin 7-O-glucuronide, quercetin 3, 7-dimethyl ether, rosmarinic acid, abietane diterpene 1, and 2) have been isolated from $C$. hadiensis. Reported anti-inflammatory, anticancer, and antibacterial activities provide scientific evidence for the ethnomedicinal uses such skin disorders, inflammations, coughs, and carcinoma. Anyway, ethnomedicinal uses to treat illnesses like diarrhea, digestive disorders, and diabetes have no scientific evidence. Noteworthy investigations (based on the minor concentrations used) are only deliberated beneath. 
Table 1. Reported in vitro bioactivities of $C$. hadiensis

\begin{tabular}{|c|c|c|c|c|c|}
\hline Bioactivity & $\begin{array}{l}\text { Part } \\
\text { used }\end{array}$ & $\begin{array}{c}\text { Extract } \\
\text { compound }\end{array}$ & Assay & $\begin{array}{c}\text { Dose } \\
\text { concentration }\end{array}$ & Reference \\
\hline Antibacterial & Aerial & Essential oil & $\begin{array}{c}\text { Escherichia coli, } \\
\text { Pseudomonas aeruginosa, } \\
\text { Staphylococcus aureus, } \\
\text { Streptococcus mutans }\end{array}$ & $\begin{array}{l}32 \mathrm{mg} / \mathrm{dl} \\
(\mathrm{MIC})\end{array}$ & $\begin{array}{l}\text { Sripathi et al., } \\
2018\end{array}$ \\
\hline \multirow[t]{3}{*}{ Antibacterial } & Leaf & $\begin{array}{l}\text { Aqueous, } \\
\text { Methanol }\end{array}$ & $\begin{array}{c}\text { Bacillus subtilis, Micrococus } \\
\text { flavus, Staphylococcus } \\
\text { aureus, Staphylococcus } \\
\text { aureus (ATCC 6538), } \\
\text { Staphylococcus epidermidis }\end{array}$ & $4 \mathrm{mg}$ & \\
\hline & Root & Aqueous & $\begin{array}{c}\text { Staphylococcus aureus } \\
\text { (ATCC 6538), } \\
\text { Staphylococcus epidermidis, } \\
\text { Staphylococcus haemolyticus }\end{array}$ & $4 \mathrm{mg}$ & $\begin{array}{c}\text { Mothana et al., } \\
2010\end{array}$ \\
\hline & Root & Methanol & $\begin{array}{l}\text { Bacillus subtilis, Micrococus } \\
\text { flavus, Staphylococcus } \\
\text { aureus, Staphylococcus } \\
\text { aureus (ATCC 6538), } \\
\text { Staphylococcus epidermidis, } \\
\text { Staphylococcus haemolyticus }\end{array}$ & $4 \mathrm{mg}$ & \\
\hline Antibacterial & Seed & Essential oil & $\begin{array}{c}\text { Escherichia coli, } \\
\text { Pseudomonas aeruginosa, } \\
\text { Staphylococcus aureus }\end{array}$ & NS & $\begin{array}{l}\text { Sripathi and } \\
\text { Ravi, } 2017\end{array}$ \\
\hline Antibacterial & $\begin{array}{l}\text { Whole } \\
\text { plant }\end{array}$ & Acetone & Bacillus subtilis & $1 \mathrm{mg} / \mathrm{ml}$ & Rijo et al., 2018 \\
\hline Anticancer & Stem & Methanol & $\begin{array}{l}\text { Cervical cancer (HeLa) cell } \\
\text { line } \\
\end{array}$ & $\begin{array}{c}141.3 \mu \mathrm{g} / \mathrm{ml} \\
\left(\mathrm{IC}_{50}\right) \\
\end{array}$ & $\begin{array}{c}\text { Menon et al., } \\
2011 \\
\end{array}$ \\
\hline Anticancer & Aerial & NS & $\begin{array}{c}\text { Human colon cancer cell } \\
\text { (HCT-15) }\end{array}$ & $17.27 \mu \mathrm{g} / \mathrm{ml}$ & $\begin{array}{c}\text { Menon and } \\
\text { Gopalakrishnan, } \\
2015 \\
\end{array}$ \\
\hline $\begin{array}{l}\text { Anti- } \\
\text { inflammatory }\end{array}$ & Stem & Methanol & $\begin{array}{c}\text { Bovine Serum Albumin } \\
\text { denaturation inhibitory, } \\
\text { Human red blood cell } \\
\text { membrane stabilization, } \\
\text { Platelet aggregation inhibitory }\end{array}$ & $1 \mathrm{mg} / \mathrm{ml}$ & $\begin{array}{l}\text { Menon et al., } \\
2011\end{array}$ \\
\hline \multirow[t]{5}{*}{$\begin{array}{c}\text { Anti- } \\
\text { inflammatory }\end{array}$} & Aerial & Ethanol $(80 \%)$ & $\begin{array}{l}\text { Bovine Serum Albumin } \\
\text { denaturation inhibitory }\end{array}$ & $\begin{array}{l}56.18 \mu \mathrm{g} / \mathrm{ml} \\
\quad\left(\mathrm{IC}_{50}\right)\end{array}$ & \\
\hline & Aerial & Ethanol $(80 \%)$ & $\begin{array}{l}\text { Human red blood cell } \\
\text { membrane stabilization }\end{array}$ & $250 \mu \mathrm{g} / \mathrm{ml}$ & \\
\hline & Aerial & Ethanol $(80 \%)$ & NO radical scavenging & $\begin{array}{c}79.84 \mu \mathrm{g} / \mathrm{ml} \\
\left(\mathrm{IC}_{50}\right)\end{array}$ & $\begin{array}{l}\text { Menon et al., } \\
2014\end{array}$ \\
\hline & Aerial & Ethanol $(80 \%)$ & Platelet aggregation inhibitory & $\begin{array}{l}54.26 \mu \mathrm{g} / \mathrm{ml} \\
\left(\mathrm{IC}_{50}\right)\end{array}$ & \\
\hline & Aerial & Ethanol $(80 \%)$ & $\begin{array}{l}\text { Potassium ferricyanide } \\
\text { reduction }\end{array}$ & $50 \mu \mathrm{g} / \mathrm{ml}$ & \\
\hline \multirow[t]{2}{*}{ Antimalarial } & Leaf & $\begin{array}{l}\text { NS (Abietane } \\
\text { diterpene 1) }\end{array}$ & Plasmodium falciparum & $4.6 \mu \mathrm{M}\left(\mathrm{IC}_{50}\right)$ & $\begin{array}{c}\text { Van Zyl et al., } \\
2008\end{array}$ \\
\hline & Leaf & $\begin{array}{l}\text { NS (Abietane } \\
\text { diterpene 2) }\end{array}$ & Plasmodium falciparum & $29.2 \mu \mathrm{M}\left(\mathrm{IC}_{50}\right)$ & \\
\hline \multirow[t]{3}{*}{ Antioxidant } & $\begin{array}{l}\text { Leaf, } \\
\text { Root }\end{array}$ & Aqueous & DPPH radical scavenging & $\begin{array}{c}>1000 \mu \mathrm{g} / \mathrm{ml} \\
\left(\mathrm{IC}_{50}\right)\end{array}$ & $\begin{array}{c}\text { Mothana et al., } \\
2010\end{array}$ \\
\hline & Leaf & Methanol & DPPH radical scavenging & $\begin{array}{c}150 \mu \mathrm{g} / \mathrm{ml} \\
\left(\mathrm{IC}_{50}\right)\end{array}$ & \\
\hline & Root & Methanol & DPPH radical scavenging & $\begin{array}{c}>1000 \mu \mathrm{g} / \mathrm{ml} \\
\left(\mathrm{IC}_{50}\right)\end{array}$ & \\
\hline
\end{tabular}




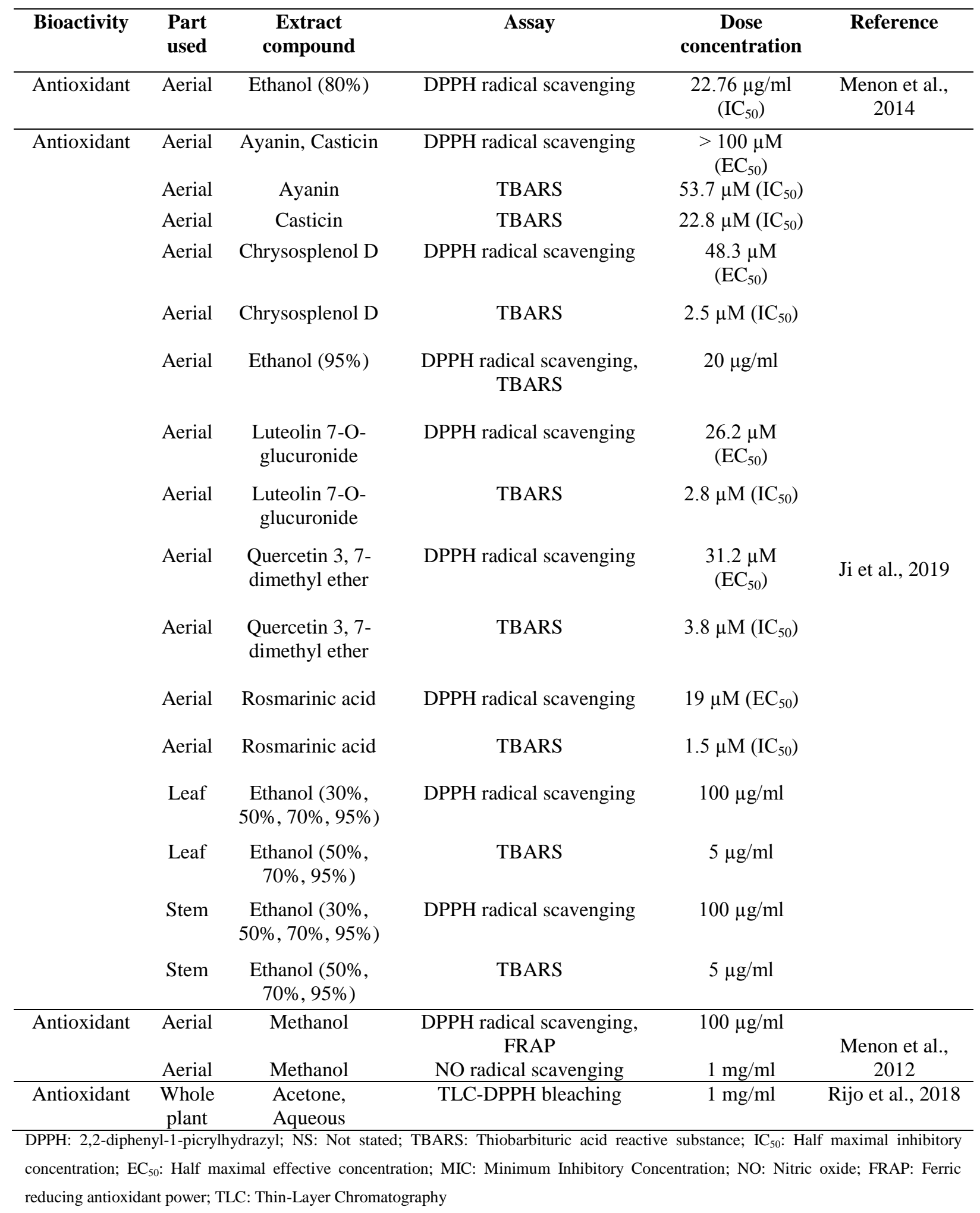




\subsection{Antibacterial activity}

Acetone extract prepared used the whole of showed antibacterial activity at $1 \mathrm{mg} / \mathrm{ml}$ concentration in Bacillus subtilis assay (Rijo et al., 2018).

\subsection{Anticancer activity}

Menon and Gopalakrishnan (2015) reported that aerial extract $(17.27 \mu \mathrm{g} / \mathrm{ml})$ showed anticancer activity human colon cancer cell (HCT-15) line (Menon and Gopalakrishnan, 2015). Anyway, the authors did not mention the solvent used to prepare the extract.

\subsection{Anti-inflammatory Activity}

Aerial ethanol $(80 \%)$ extract showed anti-inflammatory effects in potassium ferricyanide reduction assay at a concentration of $50 \mu \mathrm{g} / \mathrm{ml}$ (Menon et al., 2014).

\subsection{Antimalarial Activity}

So far, two antimalarial compounds have been identified from leaves this plant species. Abietane diterpene 1 and 2 revealed antimalarial properties in Plasmodium falciparum assay at $\mathrm{IC}_{50}$ of $4.6 \mu \mathrm{M}$ and 29.2 $\mu \mathrm{M}$ respectively (Van Zyl et al., 2008).

\subsection{Antioxidant activity}

Antioxidant compounds including ayanin, casticin, rosmarinic acid, chrysosplenol D, luteolin 7-O-glucuronide, and quercetin 3,7-dimethyl ether have been discovered in $\mathrm{C}$. hadiensis (Ji et al., 2019). Among these compounds, rosmarinic acid isolated from aerial part unveiled antioxidant effects in thiobarbituric acid reactive substance assay at $\mathrm{IC}_{50} 1.5 \mu \mathrm{M}$.

\section{Conclusion}

Published bioactivities related articles involving C. hadiensis parts provide some scientific evidence for its ethnomedicinal uses. Still, some other ethnomedicinal uses have no scientific evidence. Thus, more bioactivities related studies should be conducted and active compounds 
should be isolated. Then these compounds should be studied further in in vitro, in vivo, and clinical trial studies. Further, toxicity studies of various extracts and isolated bioactive compounds should be conducted for safety and efficacy determinations. As this plant species exhibited several bioactivities in various in vitro assays only, these bioactivities should be further studied in suitable in vivo models. These studies would provide new drugs for killer diseases like cancer in the future. This minireview analyzed, summarized, and documented the reported bioactivities of $C$. hadiensis. In addition, this minireview provides a basis for further bioactivities researches using $C$. hadiensis in future.

\section{Acknowledgements}

This work received no funding. The authors are grateful for their family members for supporting to deliver this work.

\section{References}

Ji, H-S., Li, H., Mo, E-J., Kim, U-H., Kim, Y-H., Park, H-Y., Jeong, T-S. 2019. Low-density lipoprotein-antioxidant flavonoids and a phenolic ester from Plectranthus hadiensis var. tomentosus, Applied Biological Chemistry, 62(1): 58.

Kew Science, Coleus hadiensis (Forssk.) A.J.Paton. Plants of the World Online, http://plantsoftheworldonline.org/taxon/urn:lsid:ipni.org:names:77201104-1, (December 2020).

Lukhoba, C.W., Simmonds, M.S.J., Paton, A.J. 2006. Plectranthus: A review of ethnobotanical uses, Journal of Ethnopharmacology, 103(1): 1-24.

Menon, D.B., Sasikumar, J.M., Latha, K. 2011. Anti-inflammatory and cytotoxic activity of methanolic extract of Plectranthus hadiensis Stem, Pharmacologyonline, 3:275-282.

Menon, D.B., Sasikumar, J.M., Latha, K. 2012. Phytochemical analysis and antioxidant activity of methanolic extract of Plectranthus hadiensis (Forssk.) Schweinf. ex Spreng. aerial parts, Indian Journal of Natural Products and Resources, 3(3): 359-65.

Menon, D.B., Sasikumar, J.M., Gopalakrishnan V.K. 2014. Antioxidant and antiinflammatory properties of terpenoid fraction isolated from the shoot of Plectranthus hadiensis, International Journal of Pharma and Bio Sciences, 5(2): B197-205.

Menon, D.B., Gopalakrishnan, V.K. 2015. Terpenoids isolated from the shoot of Plectranthus hadiensis induces apoptosis in human colon cancer cells via the mitochondria-dependent pathway, Nutrition and Cancer, 67(4): 697-705.

Mothana, R.A.A., Abdo, S.A.A., Hasson, S., Althawab, F.M.N., Alaghbari, S.A.Z. et al. 2010. Antimicrobial, antioxidant and cytotoxic activities and phytochemical screening of some yemeni medicinal plants, Evidence-Based Complementary and Alternative Medicine, 7(3): 323-330.

Rice, L.J., Brits, G.J., Potgieter, C.J., Staden, J.V. et al. 2011. Plectranthus: a plant for the future?, South African Journal of Botany, 77(4): 947-959. 
Rijo, P., Mariana, B., Marisa, M., Helga, R., Sandra, J. et al. 2018. Screening of antioxidant and antimicrobial activities on Plectranthus spp. extracts, Journal Biomedical and Biopharmaceutical Research, 9(2): 225-235.

Sathasivampillai, S.V., Rajamanoharan, P.R., Munday, M., Heinrich, M. et al. 2015. Preparations and plants used to treat diabetes in Sri Lankan siddha medicine. In: Colombo: Institute of Indigenous Medicine, University of Colombo.

Sathasivampillai, S.V., Rajamanoharan, P.R., Munday, M., Heinrich, M. et al. 2017. Plants used to treat diabetes in Sri Lankan siddha medicine - An ethnopharmacological review of historical and modern sources, Journal of Ethnopharmacology, 198: 531-599.

Sathasivampillai, S.V., Rajamanoharan, P.R., Munday, M., Heinrich, M. et al. 2018. Siddha medicine in eastern Sri Lanka today-continuity and change in the treatment of diabetes, Frontiers in Pharmacology, 9.

South African National Biodiversity Institute, http://pza.sanbi.org/coleus-hadiensis, (December 2020).

Sripathi, R., Dharani, J., Subban, R. 2018. A study on the seasonal variation of the essential oil composition from Plectranthus hadiensis and its antibacterial activity, Natural Product Research, 32(7): 871-874.

Sripathi, R., Subban, R. 2017. Chemical composition and antibacterial activity of the essential oil from the seeds of Plectranthus hadiensis, International Journal of Pharmacognosy and Phytochemical Research, 9(5): 637-639.

Van Zyl, R.L., Khan, F., Edwards, T.J., Drewes, S.E. 2008. Antiplasmodial activities of some abietane diterpenes from the leaves of five Plectranthus Species, South African Journal of Science, 104(1-2): 62-64. 